\title{
Wave attenuation potential, sediment properties and mangrove growth dynamics data over Guyana's intertidal mudflats: assessing the potential of mangrove restoration works
}

Üwe S.N. Best ${ }^{13}$, Mick van der Wegen ${ }^{12}$, Jasper Dijkstra ${ }^{2}$, Johan Reyns ${ }^{123}$, Bram C. van Prooijen ${ }^{3}$, and Dano Roelvink ${ }^{123}$

${ }^{1}$ IHE Delft Institute for Water Education, PO Box 3015, 2601 DA Delft, The Netherlands;

${ }^{2}$ Deltares, P.O. Box 177, 2600 MH Delft, The Netherlands;

${ }^{3}$ Delft University of Technology, Postbus 5, 2600 AA Delft;

Correspondence to: Üwe S.N. Best (u.best@un-ihe.org)

\section{Abstract}

Coastal mangroves, thriving at the interface between land and sea, provide robust flood risk reduction. Projected increases in the frequency and magnitude of climate impact drivers such as sea level rise, wind and wave climatology reinforce the need to optimize the design and functionality of coastal protection works to increase resilience. Doing so effectively requires a sound understanding of the local coastal system. However, data availability particularly at muddy coasts remains a pronounced problem. As such, this paper captures a unique dataset for the Guyana coastline and focuses on relations between vegetation (mangrove) density, wave attenuation rates and sediment characteristics. These processes were studied along a cross-shore transect with mangroves fringing the coastline of Guyana. The data are publicly available at 4TU Centre for Research Data via https://doi.org/10.4121/c.5715269 (Best et al., 2022) where the Collection: Advancing Resilience Measures for Vegetated Coastline (ARM4VEG), Guyana comprises of six key datasets.

Suspended-sediment concentrations typically exceeded $1 \mathrm{~g} / \mathrm{l}$ with a maximum of $60 \mathrm{~g} / \mathrm{l}$, implying that we measured merely fluid mud conditions across a $1 \mathrm{~m}$ depth. Time series of wind waves and fluid-mud density variations, recorded simultaneously with tide elevation and suspended sediment data, indicate that wave/fluid-mud interactions in the nearshore may be largely responsible for the accumulation of fine, muddy sediment along the coast. Sediment properties reveal a consolidated underlying bed layer. Vegetation coverage densities in the Avicennia dominated forest were determined across the vertical with maximum values over the first $20 \mathrm{~cm}$ from the bed due to the roots and pneumatophores.

Generalized total wave attenuation rates in the forest and along the mudflat were between $0.002-0.0032 \mathrm{~m}-1$ and $0.0003-0.0004 \mathrm{~m}-1$ respectively. Both the mangroves and the mudflats have a high wave damping capacity but the wave attenuation in the mangroves is presumably dominated by energy losses due to vegetation drag, since wave attenuation due to bottom friction and viscous dissipation on the bare mudflats is significantly lower than those inside the mangrove vegetation. Data collected corroborate the coastal defence function of mangroves by quantifying their contribution to wave attenuation and sediment trapping. The explicit linking of these properties to vegetation structure facilitates modelling studies investigating the mechanisms determining the coastal defence capacities of mangroves. 
Mangroves belts are key ecosystems residing in the intertidal area of tropical and sub-tropical coastlines and a key component in the discussion of green-grey infrastructure (Blankespoor et al., 2017; Kg et al., 2017; Horstman et al., 2014; Beck, 2016; Borsje et al., 2011; Bao, 2011). Although, there has been much debate about the quantifiable integration of mangroves into engineered coastal protection works (Feagin et al., 2010; Van Zelst et al., 2021; Tusinski and Verhagen, 2014; Dasgupta et al., 2017), the knowledge on the importance of mangroves has been highlighted and discussed by several authors (Zhang et al., 2012; Tusinski and Verhagen, 2014; Sasmito et al., 2016). Mangroves have a high tolerance for harsh conditions in the intertidal area: tidal flooding, exposure to waves and varying degrees of salinity(Mazda et al., 1997; Mazda et al., 2006; Hogarth, 2015; Willemsen et al., 2015). Forming a buffer between land and sea, in areas with and without robust sea defences, mangroves contribute to the attenuation of wave energy and to the stabilization of the foreshore (Pilato, 2019; Hong Phuoc and Massel, 2006; Horstman, 2014). Waves propagating through submerged and emergent vegetation lose energy due to the turbulent flow separation induced by the stems, roots and branches, resulting in the creation of a drag force. The amount of dissipated wave energy depends upon the mangrove height, surface area, location, density, distribution and root structure (Dalrymple et al., 1984; Mcivor et al., 2012b). Despite, these invaluable ecosystem services, mangrove coverage is on a rapid decline (Food and Organization, 2007; Spalding, 2010). Therefore, there is a vital need to explore in depth the physical contribution of mangroves locally to reducing coastal vulnerability to hazards such as sea level rise and extreme waves in order to adequately optimize the project planning and designing phases for green- grey infrastructure.

Along the Guyana coastline, a major mangrove coast from a global perspective, the area is under pressure from landward side due to the changes in land use (agricultural to residential). Large parts of the mangroves have been removed for fisheries and sea defences. From the seaward side, the mudbank dynamics offshore influence the sediment delivery towards the mangrove area. The combined impact from landward and seaward reduces the possibilities for mangrove regeneration. In the late $18^{\text {th }}$ century the mangrove belt covered the entire Guyana coastline, with the exception of the main river outlets. However, a $72 \%$ reduction in the mangrove coverage was reported in 2001, with the largest remaining intact mangrove system situated along the Waini-Pomeroon coast in Region 1 (Bovell, 2019). Large areas of the coast have become effective monoculture stands of Avicennia, more so with the planting of this species during the nationwide restoration works (Augustinus, 1978). Traditionally three species were observed, of which the Black mangrove (Avicennia germinans) was the dominant species. The other secondary species include the Rhizophora mangle (Red mangrove), and Laguncularia racemosa (White mangrove) which vary in density along the coastal plain. On the large developing sand banks and mudflats that dominate the coast in the west Corentyne Region, Laguncularia and Avicennia are both pioneering species within the mudflats. But, along the lower East Coast of Guyana, Laguncularia has colonized parts of the small developing mudflats. Augustinus (1978) proposed that "the sling-mud along the coast of the Guianas is so little consolidated that it can be fluidized by wave action to a certain depth", thus preventing the settlement of Rhizophora. Contrastingly, Avicennia embryos can establish in this regime, and so Avicennia becomes the single pioneering species.

70 With the country's initiation of the mangrove restoration programme in 2010, the Guyana Mangrove Restoration and Management Department, has taken strides towards advancing the protection and expansion of these greenbelts through a combination of efforts on a national scale and site specific (planting seedlings, incorporating green-grey solutions through the combination with geotextile breakwaters, brushwood dams and, restoring the hydrological functions) (Bovell, 2019). However, Guyana's remaining mangrove forests are threatened by a range of natural and man-made 
factors. Natural threats to mangroves in Guyana include natural erosive and accretive cycles characteristic of the coastline of the Guianas (Amazon river to the Orinoco river) with the large-scale mud bank movements (Augustinus, 1978). The area in between two mudbanks is referred to as the interbank area. Behind a mudbank, the hydrodynamic conditions are mild, and the coastline can accrete, whilst the coastline of the interbank area is exposed directly to ocean waves -coastlines then erode. The man-made factors affecting mangroves include the direct loss of habitat as a result of land development for housing and urban development, agriculture and aquaculture and infrastructure development (e.g. canals, sea defence infrastructure, power lines etc). Therefore, the recognition of the vital ecosystem functions of mangroves, threats and the rising cost of maintenance of the sea defence structures, is a necessity in initiating sustainable mechanisms (infrastructural, community-based, institutional), for Guyana's coastal hinterland.

These sustainable mechanisms encompass data driven (hydrodynamics, mangrove species adaptation to changing boundary conditions and resilience to climate change, extreme condition analysis, geomorphology and mangrove mudbank monitoring) projects to steer the economical and efficient management of the coastal zone. Therefore, the enhancement of the knowledge on the contributing processes determining wave attenuation in mangroves requires mechanistic studies of the propagation of waves through vegetation. Recent advances in numerical modelling explicitly resolve vegetation induced drag forces by integrating friction forces over a composition of one or several layers of rigid vertical cylinders e.g. (Best, 2017; Vo-Luong and Massel, 2008; Jacobsen and Mcfall, 2019). For a reliable representation of the vegetation, this approach compels detailed, site specific information on vegetation characteristics such as stem and root diameters, vertical vegetation distribution, vegetation densities and (bulk) drag coefficients. Field data comprising accurate measurements of both hydrodynamics (wave heights, water depths and, if possible, flow velocities) and vegetation parameters is indispensable for further development of the abovementioned numerical models (Smits, 2016; Horstman et al., 2014; Mcivor et al., 2012a; Mcivor et al., 2012b). Both hydrodynamics and vegetation parameters are changing from site to site, depending on local geography, wave climate and vegetation composition. Mazda et al. (1997) identified detailed vegetation parameters and quantifying the volume of submerged mangrove biomass. This concept will be deployed in the present paper.

This paper addresses measured correlations between vegetation densities, wave attenuation, sediment characteristics and sedimentation rates in mangroves. It forms the first extensive dataset for the Guyana coastline describing the attenuating capacity of the mangroves as well as the morphological development. We aim to correlate the total wave attenuation through a mangrove system with the volume-percentage of submerged mangrove biomass for variable vegetation compositions and densities, pursuing an explicit relation between the mangrove density and the wave attenuation capacity of mangroves. Along with these bio-physical interactions, we aim to link the attenuated hydrodynamic conditions to sediment properties within mangroves. These correlations will be based on the results of a comprehensive field campaign along a cross-shore transect through the mangrove fringe, combining measurements of the hydrodynamics and sediment dynamics at multiple positions along these transects with the collection of detailed topographic and vegetation data.

This paper describes the datasets obtained in 2019 and 2020. The Advancing Resilience Measures for Vegetated

110 Coastline (ARM4VEG), Guyana dataset is accessible via https://doi.org/10.4121/c.5715269. The repositories include the raw and processed data as well as relevant metadata and processing scripts (Best et al., 2022). 


\section{$2 \quad$ Data collection field site}

\subsection{System characteristics}

The data collection site is located in the fringing mangroves along the north eastern coastline of Guyana's coastal plain (as defined in Fig. 1 A and Fig. 1 B). This area forms part of the $1600 \mathrm{~km}$ long coastal system that is dominated by extensive mudbanks which migrate westward from the Amazon Delta in Brazil to the Orinoco Delta in Venezuela in a wave-form with crests (high bed levels and concentrations) and troughs (low bed levels and concentrations). The wavelength of these mudbanks varies from $25-50 \mathrm{~km}$, with an approximate average of $40 \mathrm{~km}$ (Allison et al., 1995; Eisma and Van Der Marel, 1971; Eisma, 1967). The presence of the wave crest - the 'bank' phase - results in increased deposition due to the reduced turbulence and increased rates of flocculation, while the coastline erodes during periods of the wave trough (the 'interbank' phase). The shoreline and nearshore subtidal areas undergo rapid changes because of the cyclic deposition and erosion patterns with the cycles averaging 30 years.

The mudbanks travel along the coast at a rate of about $1-3 \mathrm{~km}$ per year. The visible intertidal part of the mudbank is characterised by a mudflat and often mangrove colonization. During the bank phase a typical transect would cover a 100- $500 \mathrm{~m}$ mangrove belt followed by $2000 \mathrm{~m}$ of intertidal mudflat adjacent to a 10- $12 \mathrm{~km}$ mudbank with levels varying between $3.5 \mathrm{~m}$ below MSL near the mudflat to $20 \mathrm{~m}$ below MSL at the seaward edge.

The Chateau Margot area, as shown in Fig. 1 C, consists of a wide vegetated mudflat with a fringe of $120 \mathrm{~m}-400 \mathrm{~m}$ in width and length of $1200 \mathrm{~m}$. The tide is semi-diurnal with an average tidal range fluctuating between $1.17 \mathrm{~m}$ during an average neap tide and $2.5 \mathrm{~m}$ during an average spring tide, with reference to the mean sea level. The tidal range is very similar along the coast and tidal filling and emptying of the Guyana coastal system occurs more or less perpendicularly to the coast so the tide hardly generates longshore currents. The Chateau Margot hinterland is approximately $1 \mathrm{~m}$ below sea level and the several kilometres of mudflat extending offshore area exposed during the low tide. The Guyana Coast is influenced by stable trade winds; strong winds and associated surges do not often occur and there are no tropical storms in the area. The strongest winds occur in the period December - March/April and vary between $3-8 \mathrm{~m} / \mathrm{s}$ from a predominant northeast direction. The currents in the Guyana coastal system are driven by the tide, trade wind and to a lesser extent by waves. The measured currents, at $25 \mathrm{~m}$ depths offshore, have a magnitude between 0.1 and $0.5 \mathrm{~m} / \mathrm{s}$ and a direction varying between $240{ }^{\circ} \mathrm{N}$ and $360^{\circ} \mathrm{N}$.

Using the data obtained from NOAA WWIII Wave Models (Global and WNA) in 2004 by Haskoning-Nederland and Delft-Hydraulics (2005) and later validated with AWAC measurements, along with the ERA5 hindcast data and historical wave data from 1969 -1971 (Table 1), the following can be concluded about the wave environment:

- The average offshore significant wave height varies between $1.25 \mathrm{~m}$ in July/August to about $2.0-2.25 \mathrm{~m}$ in December/January with a historical maximum of $4 \mathrm{~m}$.

- The peak wave period varies between $6-10 \mathrm{~s}$ with an average of $7.5 \mathrm{~s}$, but during the months of September to April the offshore peak period may increase to $16 \mathrm{~s}$. This increase was observed $3-5$ times per year and may be attributed to tropical storms or hurricanes in the Atlantic Ocean or Caribbean Sea, as well as from severe depressions originating from the northern part of the Atlantic Ocean (Van Ledden et al., 2009).

- Wave originates from the North - North-easterly directional sector and varies between $45^{\circ} \mathrm{N}$ and $75^{\circ} \mathrm{N}$ offshore. 


\subsection{Rationale for transect alignment}

Chateau Margot is open to the oceanic swells generated by the northeast trade winds, which propagate along the coast refracting around the large expanse of Avincennia germinans along the coastline. The area was restored by the Guyana Mangrove Restoration Project with the planting of 13,000 seedlings in 2011. Over time, the Avicennia germinans has established itself as the dominant species with the secondary establishment of Lunguncularia racemosa, Rhizophora mangle and salt marshes.

Given the limitation of the wave direction to the north eastern directional sector, determined by the ERA 5 hindcast data for the years 1979 - 2017, the wave attenuation measurement transect was aligned in the predominant incoming wave direction, i.e. north east as shown in Fig. 2 A. The transect featured a gently sloping foreshore with an average of 1:1500. The zonation patterns can be observed in Fig. 2 B. Along this transect, eight measurement locations were selected to ensure maximum coverage of the area and representation of the variability within the fringe (Fig. 2 A).

All instruments were deployed five times along the transect MB. Deployments during the period $2019-2020$ spanned: 22 - 23 November, 24 - 29 November, 3 - 9 December, 12 - 17 December, 20 - 28 December and 1 - 11 January. Within the mangroves, deployment coincided with the falling tide, while deployment on the mudflat was achieved during the rising tide. A description of all of the measurement stations is shown in Table 2.

\subsection{Bed level elevation survey}

We mapped the topography of the collection site thoroughly using a combination of the Precision Automatic Level, echo sounder and a theodolite. A permanent bench mark (PBM) was first established at the base of the earthen embankment by transferring a nearby benchmark (located at the pump station). A quadrant of $1000 \mathrm{~m}$ (parallel to the dyke) by $3500 \mathrm{~m}$ (extending offshore from the edge of the dyke) was established and subdivided using 11 transects spaced at $100 \mathrm{~m}$ within the mangroves while along the mudflat a $100 \mathrm{~m}$ spacing was used. Along each transect, measurements were then taken every 10 m extending seaward.

Within the mangroves, a combination of the automatic level and theodolite were used. The limited satellite coverage within the mangroves prevented the use of instruments such as the Differential GPS. Along the mudflat, the depths were attained using a single-beam echo sounder mounted on a small boat. These measurements were taken over the course of four days to complete ten of the thirteen transects along the mudflat. Due to the shallow water depths $(1-5 \mathrm{~m})$ the single beam echo sounder gives quite accurate results and offers significant cost saving over the multi-beam versions. Due to the shallow depths in the first $1000 \mathrm{~m}$ of the mudflat (maximum $0.6-1 \mathrm{~m}$ at HW), this area was inaccessible with the boat and the echosounder which required a $1 \mathrm{~m}$ immersion depth. Depths in this section, were then derived using the GEBCO bathymetry measurements for 2019 and 2020.

\subsection{Sediment data collection}

Soil samples were collected at all eight measurement stations along the transect (Fig. 2) from the surface layers at depths between $2-5 \mathrm{~cm}$. For this campaign, two OBSs were used, T9012 and T9011. Both were tested and calibrated prior to use by Nortek. However, during the calibration process, OBS 3+ T9011 malfunctioned. This resulted in the use of the OBS 3+ T9012 to test the field sediment samples (within the mangrove \& on the mudflat). As such, its calibration curve was used to convert the instrument's power signal (V) to turbidity (NTU). The turbidity and concentration values were 
then used to form a relation, which was later used in the post processing .Water samples were also collected to corroborate the field measurements taken by the OBSs at three points near-bottom, mid-depth and near-surface. These samples were taken on the 3 December 2019, 20 December 2019, 8 January 2020 and were analysed at the laboratory of the Ministry of Public Works in Guyana in accordance with the applicable ASTM standards) and 15 July 2021. The analysis was geared towards describing the process of sedimentation of the cohesive samples (settling velocity) which has been shown to be related to the sediment concentration. In saline suspensions with sediment concentrations up to 1 $\mathrm{g} / \mathrm{l}$, an increase in the settling velocity coincides with increasing concentrations, while the settling velocity in in-situ samples was observed to decrease with increasing concentrations in excess of $10 \mathrm{~g} / \mathrm{l}$.

Along the transect, sediment properties (dry and bulk density, grain size, water content and Atterberg limits, particle size distribution and organic matter content) were determined as well. These values will typically filter into the parameters applied in numerical modelling practices.

\subsection{Mangrove vegetation survey}

High resolution vegetation data obtained during the campaign was transformed into vegetation cover, expressing the relative vegetation coverage of the horizontal surface. The quantification of the vegetation elements was achieved using $10 \mathrm{~m} \mathrm{x} 10 \mathrm{~m}$ quadrants along all of the transects. The quadrants were spaced at $30 \mathrm{~m}$, with the exception of the initial $20 \mathrm{~m}$ between the seawall and the first quadrant. With the vegetation cover at varying depths across the eleven transects, correlation was then determined with the observed wave dissipation.

The vegetation survey method further divided each quadrant into three equally spaced transects, along which all trees were tagged and the characteristics such as the height, diameter and species were recorded. This random sample was then used as a full representation of the characteristics within the quadrant. The diameter of the tree trunks was measured at stipulated heights: $0.1 \mathrm{~m}, 0.5 \mathrm{~m}, 1 \mathrm{~m}, 1.5 \mathrm{~m}, 2 \mathrm{~m}$ and at breast height, $1.3 \mathrm{~m}$ (where possible). This procedure applied to both the Avicennia germinans and Laguncularia racemosa species, however for the Rhizophora mangrove (often very sparse and young trees), additional extensive details were recorded for the prop roots. All Rhizophora trees in the plots were counted and diameters of all roots, stems and branches were measured at the same elevations above the bed. The overall height of the tree was also recorded with the aid of the surveying staff and a fabricated measuring rod.

For the seedlings within the quadrant, a $1 \mathrm{~m}$ x $1 \mathrm{~m}$ quadrant was used at three random locations within the $10 \mathrm{~m} \times 10 \mathrm{~m}$ vegetation plot to count the number of seedlings and pneumatophores, and determine their height and diameter. The height and diameter of the pneumatophores were measured for 20 randomly chosen pneumatophores per subplot $(1 \mathrm{~m}$ $\mathrm{x} 1 \mathrm{~m}$ ). In the post processing, the diameters measured were categorized in three groups: $0-40 \mathrm{~mm}, 40-90 \mathrm{~mm}$ and $90-130 \mathrm{~m}$

Salinity and temperature readings were taken at three randomly spaced points within the transect. This process was documented with scaled photographs for qualitative characterization of the geometry and the interaction with the hydrodynamics.

The vegetation data was then transformed into spatially explicit vegetation densities. In achieving this, the data was first transformed into the total horizontal coverage of vegetation elements within each of the $10 \mathrm{~m} \times 10 \mathrm{~m}$ quadrants at different levels above the bed. After which, the volume of the vegetation within a water column of arbitrary depth was calculated by integrating the horizontal vegetation coverage over the depth. The density was then expressed as the relative vegetation volume compared to the total submerged volume. 


\subsection{Hydrodynamic data collection}

Eight (8) high quality sensors, consisting of a mixture of pressure transducers (PTs) and Acoustic Doppler Velocimeters (ADVs) were deployed for collecting wave data, water levels and currents along the transect MB shown in Fig. 2. These sensors are robust and the internal memory and battery housing facilitated autonomous data collections for periods of up to several weeks, depending on the sampling frequency and battery quality.

Six (6) pressure transducers (PTs) were used to collect the water levels and wave heights. These were deployed at stations MB 1, MB 2, MB 4, MB 6, MB 7 and MB 8 over the seven weeks of the field campaign. The setup of the wave loggers, in addition to the ADVs, is intended to capture the wave attenuation over the mudflat as well as within the fringe, and the fringe potential to attenuate both the swell and infragravity waves. As a result, the PTs were configured to record pressure data continuously at a $5 \mathrm{~Hz}$ sampling frequency. The PTs were placed at heights above the bed ranging between $5-15 \mathrm{~cm}$, but most deployments tried to maintain a height of $6 \mathrm{~cm}$ above the bed in order to start the data collection at shallow water depths.

Two ADVs were used to collect water level data, flow velocity and flow directional data as well as data regarding the suspended sediment concentration. The ADVs collected data at a sampling interval of $30 \mathrm{mins}$ and a frequency of $4 \mathrm{~Hz}$ over 20 min. bursts lengths. The ADVs were deployed at two locations, MB 3 and MB 5 over five deployments spanning the period of seven weeks. This allowed for the cleaning of the sensors from blockages due to the high sediment concentrations. The probe was placed at $13 \mathrm{~cm}$ above the bed within the mangroves to ensure that it would be immersed during neap/ low tide. Station MB 3 was located within the mangrove fringe while station MB 5 was located on the mudflat. The frames were positioned perpendicular to the prevailing tidal flow direction to ensure that minor disturbances, if any, were created.

Next to these high-frequency pressure transducers, low-frequency pressure (and temperature) loggers (Conductivity, Temperature \& Depth loggers (CTD)) were deployed during the field campaign. The CTD logger (Fig. 4 B) was setup at station MB 1 and collected pressure data with a sampling interval of 5 minutes.

\subsection{Processing hydrodynamic data}

Obtained pressure data from the pressure transducers were corrected for the atmospheric pressure prior to the conversion to water depths using linear wave theory. Meteorological data correlated well with the measurements of the CTD and showed that the atmospheric pressure ranged between $10.26-10.45 \mathrm{~m} \mathrm{H}_{2} \mathrm{O}$.

For both sets of instruments, the resulting data is pre-processed using filtering, averaging and data correction, similar to Horstman (2014). Inaccurate data is removed by only selecting data above a mean correlation threshold for the return signals of the ADV's receiver probes, which is $80 \%$ (Colosimo et al., 2020; Chanson et al., 2008). Due to the filtering procedure major disturbances (e.g. fishing boats) and minor disturbances (e.g. air bubbles) were removed. The filtered data showed continuous data without gaps throughout the duration of the deployment.

Spectral analysis of the obtained wave signal was executed according to the Hegge and Masselink (1996) Fourier analysis scheme, resulting in wave energy density spectra for each burst. From these energy density spectra, the total significant wave height $\mathrm{H}_{\mathrm{m} 0}(\mathrm{~m})$, mean wave period $\mathrm{T}_{\mathrm{m} 01}(\mathrm{~s})$ and total wave energy $\mathrm{E}_{\mathrm{tot}}\left(\mathrm{J} / \mathrm{m}^{2}\right)$ were derived for each burst of the wave data. Subsequently, data bursts were selected for time spans during which the entire transect was flooded. This selection allowed the assimilation of coherent datasets of the wave characteristics at the measurement stations. The swell $(>0.04 \mathrm{~Hz})$ and infragravity $(<0.04 \mathrm{~Hz})$ wave bands were then selected using a bandpass filter to 
ascertain their presence and magnitude within the mangrove fringe.

\section{$3 \quad$ Results}

\subsection{Mangrove density}

The measurements showed on average 12 seedlings per quadrant along every transect. There were six to eight quadrants per transect allowing for the properties of a total of 1056 trees, both black and white mangroves, to be captured. The Avicennia germinans was seen to be the dominant species with the Languncularia racemosa and the Rhizophora mangle being secondary species (Fig. 5). However, further west of the central transect (transects 10 and 11), the Languncularia racemosa, was equally balanced with the Avicennia germinans in the outer quadrants as seen in Fig. 5. Noticeably, the Languncularia species had very thin stem diameters as compared to the Avicennia but the heights were comparable. The data revealed the relationships between the mangrove height and stem diameter for the two-dominant species ten years after the restoration. The maximum stem diameter and height for the Avicennia were $12 \mathrm{~cm}$ and $1300 \mathrm{~cm}$ respectively, while the Languncularia was characterized by a maximum height and diameter of $1200 \mathrm{~cm}$ and $7 \mathrm{~cm}$ respectively.

The high-resolution data were transformed into the vegetation parameter $A_{M} / V$ (where $A_{M}$ is the area of the obstacles and V is the total submerged volume), which according to Mazda et al. (1997), is key in representing the hydrodynamics in mangrove fringes. In addition, Petryk and Bosmajian (1975) defined the vegetation density by $A_{M} / \mathrm{V}$, but noted slight variations with increasing water depths. The vegetation parameter was calculated from measurements of the number trunks, pneumatophores, and their elements in all quadrants (Fig. 6). For the calculation of the area, the shapes of the trunks and pneumatophores were simplified to a cylinder.

At the mean height of the pneumatophores, approximately $5 \mathrm{~cm}$, the vegetation coverage for the Avincennia germinans was quite high ranging from $16-50 \%$ (Fig. 6) due to the dense cover of the roots varying from $135-400$ pneumatophores $/ 100 \mathrm{~m}^{2}$ (Fig. $5 \mathrm{C}$ and Fig. 6). Above this layer, at $10 \mathrm{~cm}$, the vegetation coverage reduces gradually due to the large diameters for the base of the trees and multiple shoots for one plant. A sharp decrease, to less than 5\%, is then observed in the vegetation coverage with increasing heights since the trunks taper off.

\subsection{Sediment properties \& bathymetry}

Along the main transect, three sets of disturbed samples were collected at each of the eight (8) measurement stations indicated in Fig. 2 ( 3 sets in vegetation and 5 sets along the bare mudflat). Within the mangrove fringe, samples were taken from the upper layers of the forest floor (consolidated mud). While on the mudflat, due to the fluid mud layer, samples were retrieved from the interface of the fluid mud and consolidated mud layers.

Sediment characteristics were averaged over two measurements for each test. In the laboratory, sediment samples were dried to determine bulk density $\left(\mathrm{g} / \mathrm{cm}^{3}\right)$. Within the fringe, the bulk density ranged from $1.39-1.66 \mathrm{~g} / \mathrm{cm}^{3}$, while the density along the mudflat ranged from $1.53-1.79 \mathrm{~g} / \mathrm{cm}^{3}$. These measurements correlated well with the range of values produced by field measurements along the Suriname coastline (Wells, 1977) . Grain size was determined using a combination of the ASTM D6913 Wet sieve method and the ASTM D7928 Hydrometer Analysis, enabling the determination of silt/clay particle diameter size between $0.0003 \mathrm{~mm}$ and $0.05 \mathrm{~mm}$.

All stations consistently showed that sediment was of a silty clay nature with varying degrees of silt. The grain size 
distribution (Fig. 7) shows a high amount of clay and silt particles in the mangrove belt (MB 1, MB 2, MB 3) and along the mudflat, where flow velocities are higher than at the back of the mangrove. The organic matter content (Table 3 ) is highest in the centre of the mangrove, similar to other studies e.g. (Horstman et al., 2015) and lower values can be found at the back of the mangrove and in the creeks. Additionally, there is some variability in the silt/ clay content in the mangroves, increasing towards the edge, but this stabilizes and is consistent along the mudflat.

The particular state of consistency of any particular soil depends primarily upon the amount of water present in the soil-water system thereby making the behaviour of soil directly related to the amount of water present. The Atterberg limit (ASTM 4318-10) represents a water content at which the soil changes from one state to another. The values of the Atterberg limits of the soil samples are shown in Table 3. The liquid limit ranges from $35 \%$ to $99 \%$ with an average liquid limit of $61 \%$. The plasticity index which indicates the degree of plasticity of a soil ranges from $15 \%$ to $66 \%$ with an average plasticity index of $36 \%$. From the results obtained, MB 1, MB 2 and MB 3 can be classified as soils with high plasticity because their plasticity indices ranged between 47 to 66; while stations MB 4, 5, 6, 7 and 8 range from medium to high plasticity clays.

Shallow water waves propagating over the muddy bottom maintains a large volume of sediment in suspension. Wells (1977), showed that during mudbank periods, the suspended concentrations are orders of magnitude higher than during the interbank periods. High concentrations were recorded by the optical backscatter instruments (OBS 3+) and frequently exceeded the measuring capacity of the instruments $(<5 \mathrm{~g} / \mathrm{l})$ (Downing, 2006). The presence of a fluid-mud bottom, with higher suspended concentrations, changes the form of incoming waves from sinusoidal to a solitary- like appearance (flatter troughs). Sediment suspension by waves is more likely to occur than by tidal currents in this region due to the solitary wave characteristics over the fluid mud, where high concentrations are observed (Wells et al., 1978; Wells and Coleman, 1981a). Wave shear stresses generally exceed the stress by tidal currents, and concentrations decay seaward.

The OBS $5+$ (and similar capacity turbidity sensors with a capacity of $50 \mathrm{~g} / \mathrm{l}$ or higher) is therefore the recommended choice for data collection campaigns along the north eastern South American coast. Field samples taken confirmed the observations from the instruments as concentrations varied between $40 \mathrm{~g} / \mathrm{l}$ to $60 \mathrm{~g} / \mathrm{l}$ along the intertidal mudflat, which is characteristic for fluid mud (Fig. 8). Fluid mud refers to the sediment-water mixture in which the sediment concentration is greater than $10 \mathrm{~g} / \mathrm{l}$ (Krone, 1962; Wells and Coleman, 1981b). The mean settling velocity was determined graphically and ranged between $0.02 \mathrm{~mm} / \mathrm{s}$ to $0.2 \mathrm{~mm} / \mathrm{s}$.

There was limited variability in the concentration across the depth, and as such the 2D-depth averaged representation is apt at capturing the nearshore processes for similar mangrove-mudflat systems. For the entire coastal plain, the movement of the mudbanks offshore dictates that spatial and temporal variations in the concentrations are expected. The measured mud concentrations (similar to Anthony (2016)), generally range from very high-suspended sediment concentrations ( $1-10 \mathrm{~g} / \mathrm{l})$, and through the fluid mud, to settled mud, ranging from under-consolidated $(<650 \mathrm{~g} / \mathrm{l})$ to over-consolidated beds (>750 g/l). Therefore, this shows the extensive depth of the fluid mud layer along the Guyana coast which exceeds often $1 \mathrm{~m}$ and potentially covers the entire water depth.

\subsection{Wave climate}

Time-averaged wave energy density spectra at all cross-shore monitoring positions are plotted for each deployment (periods with spectra for less than eight positions are due to malfunctioning sensors). Obtained wave data cover a wide 
range of tidal conditions, although neap tides are poorly represented in the data as water levels remained too low to flood the entire transect.

Despite the high-energy period observed over the last deployment (Fig. 9 and Fig. 11) there were overall periods with moderate wave conditions (Fig. 10). The wave energy density spectra at the front most monitoring positions at both transects were found to be independent of the local water depth. In general, the observed wave energy was low during the first two periods of data collection (Fig. 9), but heightened from mid December when wind directions turned onshore. Wave energy increased during the subsequent deployments with the most energetic conditions being observed in the December/January deployment (Fig. 9, Fig. 10). This may be attributed to tropical storms or hurricanes in the Atlantic Ocean or Caribbean Sea, as well as from severe depressions originating from the northern part of the Atlantic Ocean ((Van Ledden et al., 2009).

The wave spectra for the Chateau transect were not characteristically uni-modal but the mean wave periods varied mainly between either $2-7 \mathrm{~s}$ for all deployments. Offshore, the wave climate is characterised by average peak periods between 6 and $10 \mathrm{~s}$ with highs of $16 \mathrm{~s}$ during the period of September to April. The transect was typically exposed to swell waves $(10-20 \mathrm{~s})$ and infragravity waves $(25-250 \mathrm{~s})$ during the deployments. The infragravity waves ranged between $5-10 \mathrm{~cm}$ in height while the swell waves were $20-80 \mathrm{~cm}$.

Local increases of the wave energy density in the swell wave regime was observed between consecutive sensors during the measurements (Fig. 9 and Fig. 10). Such an increase of the energy density of the low-frequency component of the energy density spectra can be induced by (i) enhanced shoaling of shorter waves and (ii) energy transfer to lower frequencies by nonlinear wave-wave interactions (Elgar and Raubenheimer, 2008).

\subsection{Cross-shore changes in wave properties}

Changes of the wave characteristics along the transects were obtained from the wave energy density spectra for each data collection period (Fig. 10). Typical incident waves did not exceed $70 \mathrm{~cm}$ in height. While the significant wave heights decreased along the transect, mean wave periods were slightly increasing towards the back of the forest. Mean wave periods changed from $4.0-4.5 \mathrm{~s}$ to $4.0-5.0 \mathrm{~s}$ (Fig. 11).

360 This is corroborated by the wave energy density spectra presented in Fig. 9, showing that the shorter sea waves (i.e. frequencies $>0.1 \mathrm{~Hz}$ ) lost more energy when propagating into the forest than the longer swell waves $(<0.1 \mathrm{~Hz})$. Hence, shorter waves got attenuated more effectively when propagating into the forest, as opposed to the longer-period swell waves that hardly got attenuated, giving rise to an increase of the mean wave periods.

Observed wave heights to measured water depths ratios ranged from $20 \%$ along the mudflat to $70 \%$ within the mangroves (Fig. 11). Wave breaking occurs for wave heights exceeding $60-83 \%$ of the water depth (Battjes and Stive, 1985). Hence, wave breaking could not have contributed significantly to the wave energy losses along the mudflat portion of the transect, but was contributed to some extent within the mangroves. Therefore, we conclude that the observed attenuation of wave energy must have been caused by drag and friction forces induced by the mangrove vegetation and interactions with the forest floor along with minimal wave breaking.

Our field observations represent relatively mild conditions with significant wave heights ranging from $0.5-1.0 \mathrm{~m}$. 
Figure 12 provides a clear depiction of the attenuating capacity of both the mudflat and the mangrove vegetation. Due to bed friction, the wave height attenuated significantly by some $85-90 \%$ over the mudflat from offshore to the edge of the mangrove fringe. The mangroves are able to reduce the height further by 50\% within the first one-third $(120 \mathrm{~m})$ of the fringe width. This corresponds well with other field measurements collected in forests in Vietnam (Cuc et al., 2015; Mazda et al., 2006; Vo-Luong and Massel, 2008). At the most landward point ( $340-360 \mathrm{~m})$, this section is predominantly dry except for spring tides. However, even during spring tides, the waves heights did not exceed $0.1-$ $0.24 \mathrm{~m}$ within the landward sections of the fringe during the field campaign. This corresponds to a further $30-40 \%$ decline in the wave height. A contrasting difference between the Guyana coast and those of Vietnam lies in the extensive layers of fluid mud which certainly contribute towards the attenuating capacity of these mudflats (Gratiot et al., 2017; Kit, 2016).

The rate of wave height reduction $(\alpha)$ per unit distance in the direction of wave propagation is defined as the reduction in wave height $\left(\Delta H_{\mathrm{s}, 0}\right)$ as a proportion of the initial wave height $\left(H_{\mathrm{s}, 0}\right)$ over a distance $(\Delta x)$ travelled by the wave (see Eq. (1)). The unit of ' $\alpha$ ' is $\mathrm{m}^{-1}$. For example, when wave height is reduced by $1 \%$ over a distance of $1 \mathrm{~m}$, then $\mathrm{r}=0.01$ $\mathrm{m}^{-1}$ as calculated using Eq. (1).

$$
\alpha=-\frac{\Delta H \mathrm{~s}, 0}{H \mathrm{~s}, 0} \cdot \frac{1}{\Delta x}
$$

Using Eq. (1), the attenuation rate within the Chateau Margot mangrove fringe corresponds to a range of $0.002-0.0032$ $\mathrm{m}^{-1}$. On the mudflats the attenuation rate varies between $0.0003-0.0004 \mathrm{~m}^{-1}$.

\section{$5 \quad$ Data availability}

390 The data presented in this paper have been published at 4TU Centre for Research Data (4TU.ResearchData) following the FAIR principles (Wilkinson et al., 2016), and can be accessed via https://doi.org/10.4121/c.5715269 (Best et al., 2022) for the public download of the entire collection: Advancing Resilience Measures for Vegetated Coastline (ARM4VEG), Guyana. The collection contains five key datasets including the in-situ concentration data, wave data, bathymetry, sediment properties and mangrove characteristics (Best et al., 2022). The datasets are published in a combination of .mat, .xlsx and .xyz formats with the file naming convention which specifies the measurement location along transect MB. A map is available, indicating the measurement locations of each dataset. The underlying raw data as produced by the instruments together with the scripts with metadata are maintained under version control. Processing scripts are written in MATLAB code and the metadata in the mat. files specify the date and version number of underlying raw source data and in order to provide replicable information.

\section{Discussion and conclusions}

This paper presents field observations of the vegetation structure across the submerged depth, including wave attenuation and sediment dynamics along one cross-shore transect in coastal mangroves in Guyana. This forms the first extensive dataset of measurements since the 1960's - 1970's during the NEDECO projects along the Suriname and Guyana coasts. The collection of wave data in combination with detailed vegetation measurements was unprecedented, but is of great importance to the further development of knowledge on the attenuation of waves on mudflats and in mangrove belts.

The detailed characterization of the vegetation cover at the data collection site emphasizes the variability of mangrove 
vegetation structure in both the vertical and the horizontal direction. Vegetation densities were strongly dependent on the dominant vegetation type. Volumetric vegetation densities within $1 \mathrm{~m}$ above the forest floor were found to be 0.91 $-2.64 \%$ in the Avicennia zones. Vegetation densities in the Laguncularia zones were (much) lower: $1.16-1.71 \%$, increasing up to $50 \%$ for water depths less than $1 \mathrm{~m}$.

Mean observed significant wave heights decreased (on average) by $50-76 \%$ by bed friction and mangrove drag along the Chateau Margot transect, which was $1620 \mathrm{~m}$ long. Wave attenuation was most efficient for short sea waves $(<10$ s), while swell waves $(10-20 \mathrm{~s})$ and infragravity waves ( $25-250 \mathrm{~s})$ tended to maintain their energy.

415 The generalized total wave attenuation rates in the mangrove belt, obtained by the gradient of the relation between wave height reduction and incident wave height, ranged between 0.002 and $0.0032 \mathrm{~m}^{-1}$ while it varied between 0.0003 and $0.0004 \mathrm{~m}^{-1}$ on the mudflat. These rates showed a significant positive correlation with the volumetric vegetation density. Further, studies show that a minimum attenuation capacity of $50 \%$ is needed to prevent wave reflection at the inner wall of the dike which would lead to increased scour volumes (Van Wesenbeeck et al., 2021; Winterwerp et al., 2020). These features can substantially reduce costs for retrofitting of levees under changing future wave climates.

These findings emphasize the coastal defence function of mangroves and provide a starting point for modelling studies to investigate the processes contributing to the attenuating and sediment trapping capacity of mangroves.

\section{$7 \quad$ Author contributions}

This study forms a section of the doctoral research of USNB. Therefore, USNB coordinated the set-up of the campaign and the frames, coordination and analysis under the supervision of MvdW, JD, JR, BCvP and DR. USNB analysed the data from the pressure transducers, acoustic doppler velocimeters (ADVs), optical backscatter sensors and Conductivity, Temperature \& Depth logger (CTD) with the guidance from JR and DR. JR also assisted in carrying out quality checks for the processed data. The collection and processed of the mangrove characteristics and sediment properties was organized and achieved by USNB. While the data analysis was done jointly between USNB, JD, JR and $\mathrm{MvdW}$. The data storage on the repository and visualizations were done by USNB. All authors participated in the writing and the proofing of the paper. Funding was acquired by DR and MvdW with the support Deltares.

\section{$8 \quad$ Competing interests}

The authors declare that they have no conflict of interest.

\section{Acknowledgements}

435 The authors gratefully acknowledge all assistance in planning, facilitating and executing fieldwork by P. Willemsen, E. Horstman, B. Van Prooijen, M. De Schipper, L. De Vet, P. Van der Gaag and S. De Vree. We would also like to thank the Hydraulic Department of Delft University of Technology, the staff of the Ministry of Public Works (MPW), Guyana Mangrove Restoration and Management Department of the National Agricultural Research \& Extension Institute (NAREI), Guyana and the Maritime Administration (MARAD), without whom this fieldwork would not have been

440 possible. All instrumentation used for the collection of the datasets were provided jointly by IHE Delft Institute for Water Education (IHE Delft), Delft University of Technology (TU Delft) and MARAD. The various logistics and manpower during the field work were coordinated with MPW, NAREI and MARAD. 
The fieldwork presented in this paper was conducted under the research permit "Mangrove- Mudflat Coastlines Impacted by Sea Level Rise (SLR)- Hydrodynamics and Sediment Dynamics, Chateau Margot Mangroves, Guyana'. It was funded jointly by the Mangrove Research of NAREI (Project \#:2019-01) and the PhD Project, 107440 (IHE Delft - Deltares).

\section{0}

\section{References}

Allison, M., Nittrouer, C., and Kineke, G.: Seasonal sediment storage on mudflats adjacent to the Amazon River, Marine Geology, 125, 303-328, 1995.

Anthony, E. J.: Assessment of peri-urban coastal protection options in Paramaribo-Wanica, Suriname, WWF Guianas, Paramaribo, Suriname, 2016.

Augustinus, P. G. E. F.: The changing shoreline of Suriname (South America), University Utrecht, 1978.

Bao, T. Q.: Effect of mangrove forest structures on wave attenuation in coastal Vietnam, Oceanologia, 53, 807-818, 2011.

Battjes, J. and Stive, M.: Calibration and verification of a dissipation model for random breaking waves, Journal of Geophysical Research: Oceans, 90, 9159-9167, 1985.

Beck, M.: Managing Coasts with Natural Solutions: Guidelines for Measuring and Valuing the Coastal Protection Services of Mangroves and Coral Reefs.(MW Beck \& G.-M. Lange, Eds.), Washington DC: The World Bank, 2016.

Best, U., van der Wegen, M., Reyns, J., Dijkstra, J., Roelvink, D., and van Prooijen, B.: Advancing Resilience Measures for Vegetated Coastline (ARM4VEG), Guyana [dataset], https://doi.org/10.4121/c.5715269, 2022.

Best, Ü. S. N.: Process-based modelling of the impact of sea level rise on salt marsh \& mangrove fringe-mudflat morphodynamics [An assessment of the decadal triggers for morphological evolution and restoration methods], UNESCO-IHE2017.

Blankespoor, B., Dasgupta, S., and Lange, G.-M.: Mangroves as a protection from storm surges in a changing climate, Ambio, 46, 478-491, 2017.

Borsje, B. W., van Wesenbeeck, B. K., Dekker, F., Paalvast, P., Bouma, T. J., van Katwijk, M. M., and de Vries, M. B.: How ecological engineering can serve in coastal protection, Ecological Engineering, 37, 113-122, 10.1016/j.ecoleng.2010.11.027, 2011.

Bovell, O.: Setting the foundations for zero net loss of the mangroves that underpin human wellbeing in the North Brazil Shelf LME: Review of the effectiveness of existing coastal restoration efforts in Guyana., 2019.

Chanson, H., Trevethan, M., and Aoki, S.-i.: Acoustic Doppler velocimetry (ADV) in small estuary: field experience and signal post-processing, Flow Measurement and Instrumentation, 19, 307-313, 2008.

Colosimo, I., de Vet, P. L. M., van Maren, D. S., Reniers, A. J. H. M., Winterwerp, J. C., and van Prooijen, B. C.: The Impact of Wind on Flow and Sediment Transport over Intertidal Flats, Journal of Marine Science and Engineering, 8, $910,2020$.

Cuc, N. T. K., Suzuki, T., de Ruyter van Steveninck, E. D., and Hai, H.: Modelling the impacts of mangrove vegetation structure on wave dissipation in Ben Tre Province, Vietnam, under different climate change scenarios, Journal of Coastal Research, 31, 340-347, 2015.

Dalrymple, R. A., Kirby, J. T., and Hwang, P. A.: Wave diffraction due to areas of energy dissipation, Journal of Waterway, Port, Coastal, and Ocean Engineering, 110, 67-79, 1984.

Dasgupta, S., Islam, M., Huq, M., Khan, Z. H., and Hasib, M.: Mangroves as protection from storm surges in Bangladesh, 2017.

Downing, J.: Twenty-five years with OBS sensors: The good, the bad, and the ugly, Continental Shelf Research, 26, 2299-2318, 2006. 
Eisma, D. and Van der Marel, H.: Marine muds along the Guyana coast and their origin from the Amazon Basin, Contributions to Mineralogy and Petrology, 31, 321-334, 1971.

Elgar, S. and Raubenheimer, B.: Wave dissipation by muddy seafloors, Geophysical Research Letters, 35, 2008.

Feagin, R. A., Mukherjee, N., Shanker, K., Baird, A. H., Cinner, J., Kerr, A. M., Koedam, N., Sridhar, A., Arthur, R., and Jayatissa, L. P.: Shelter from the storm? Use and misuse of coastal vegetation bioshields for managing natural disasters, Conservation Letters, 3, 1-11, 2010.

Food, U. and Organization, A.: The World's Mangroves 1980-2005: a thematic study prepared in the framework of the Global Forest Resources Assessment 2005, 2007.

Gratiot, N., Bildstein, A., Anh, T. T., Thoss, H., Denis, H., Michallet, H., and Apel, H.: Sediment flocculation in the Mekong River estuary, Vietnam, an important driver of geomorphological changes, Comptes Rendus Geoscience, 349, 260-268, 2017.

Haskoning-Nederland and Delft-Hydraulics, W.: Institutional Capacity Building Activities on Guyana Sea Defences Modelling Report Volume 1: Executive Summary, 9M5198.21/RG047/WL / H4095, 2005.

Hegge, B. J. and Masselink, G.: Spectral analysis of geomorphic time series: auto-spectrum, Earth Surface Processes and Landforms, 21, 1021-1040, 1996.

Hogarth, P. J.: The biology of mangroves and seagrasses, Oxford University Press2015.

Hong Phuoc, V. and Massel, S. R.: Experiments on wave motion and suspended sediment concentration at Nang Hai, Can Gio mangrove forest, Southern Vietnam, Oceanologia, 48, 2006.

Horstman, E.: The mangrove tangle: short-term bio-physical interactions in coastal mangroves, 2014.

505 Horstman, E., Dohmen-Janssen, C. M., Narra, P., Van den Berg, N., Siemerink, M., and Hulscher, S. J.: Wave attenuation in mangroves: A quantitative approach to field observations, Coastal engineering, 94, 47-62, 2014.

Horstman, E. M., Dohmen-Janssen, C. M., Bouma, T. J., and Hulscher, S. J.: Tidal-scale flow routing and sedimentation in mangrove forests: Combining field data and numerical modelling, Geomorphology, 228, 244-262, 2015.

Jacobsen, N. G. and McFall, B. C.: A frequency distributed dissipation model for canopies, Coastal Engineering, 150, 135-146, 2019.

KG, P., PA, U., and Bhaskaran, P. K.: Inter-seasonal variability of wind-waves and their attenuation characteristics by mangroves in a reversing wind system, International Journal of Climatology, 37, 5089-5106, 2017.

Kit, L. W.: Wave Attenuation Function of Mangroves Along Singapore's Northern Coast, 2016.

Krone, R. B.: Flume studies of transport of sediment in estrarial shoaling processes, Final Report, Hydr. Engr. and Samitary Engr. Res. Lab., Univ. of California, 1962.

Mazda, Y., Magi, M., Ikeda, Y., Kurokawa, T., and Asano, T.: Wave reduction in a mangrove forest dominated by Sonneratia sp, Wetlands Ecology and Management, 14, 365-378, 2006.

Mazda, Y., Wolanski, E., King, B., Sase, A., Ohtsuka, D., and Magi, M.: Drag force due to vegetation in mangrove swamps, Mangroves and Salt Marshes, 1, 193-199, 1997.

520 McIvor, A., Möller, I., Spencer, T., and Spalding, M.: Reduction of wind and swell waves by mangroves, The Nature Conservancy and Wetlands International, 2012a.

McIvor, A., Spencer, T., Möller, I., and Spalding, M.: Storm surge reduction by mangroves, The Nature Conservancy and Wetlands International, 2012b.

Petryk, S. and Bosmajian, G.: Analysis of flow through vegetation, Journal of the Hydraulics Division, 101, 871-884, 1975. 
Pilato, C.: Hydrodynamic Limitations and the Effects of Living Shoreline Stabilization on Mangrove Recruitment along Florida Coastlines, 2019.

Sasmito, S. D., Murdiyarso, D., Friess, D. A., and Kurnianto, S.: Can mangroves keep pace with contemporary sea level rise? A global data review, Wetlands Ecology and Management, 24, 263-278, 2016.

530 Smits, B.: Morphodynamic optimisation study of the design of semi-permeable dams for rehabilitation of a mangrovemud coast: A case study of the Building-with-Nature project in Demak, Indonesia, 2016.

Spalding, M.: World atlas of mangroves, Routledge2010.

Tusinski, A. and Verhagen, H. J.: The use of mangroves in coastal protection, Coastal Engineering Proceedings, 1, 45, 2014.

535 van Ledden, M., Vaughn, G., Lansen, J., Wiersma, F., and Amsterdam, M.: Extreme wave event along the Guyana coastline in October 2005, Continental Shelf Research, 29, 352-361, 2009.

van Wesenbeeck, B. K., Wolters, G., Antolínez, J. A., Kalloe, S., Hofland, B., de Boer, W., Çete, C., and Bouma, T. J.: Woods versus waves: Wave attenuation through non-uniform forests under extreme conditions, 2021.

van Zelst, V., Dijkstra, J. T., van Wesenbeeck, B. K., Eilander, D., Morris, E. P., Winsemius, H. C., Ward, P. J., and de

540 Vries, M. B.: Cutting the costs of coastal protection by integrating vegetation in flood defences, Nature communications, $12,1-11,2021$.

Vo-Luong, P. and Massel, S.: Energy dissipation in non-uniform mangrove forests of arbitrary depth, Journal of Marine Systems, 74, 603-622, 2008

Wells, J. T.: Shallow-Water Waves and Fluid-Mud Dynamics, Coast of Surinam, South America, Louisiana State University and Agricultural \& Mechanical College1977.

Wells, J. T. and Coleman, J. M.: Physical processes and fine-grained sediment dynamics, coast of Surinam, South America, Journal of Sedimentary Research, 51, 1053-1068, 1981a.

Wells, J. T. and Coleman, J. M.: Periodic mudflat progradation, northeastern coast of South America; a hypothesis, Journal of Sedimentary Research, 51, 1069-1075, 1981b.

550 Wells, J. T., Coleman, J. M., and Wiseman Jr, W. J.: Suspension and transportation of fluid mud by solitary-like waves, in: Coastal Engineering 1978, 1932-1952, 1978.

Wilkinson, M. D., Dumontier, M., Aalbersberg, I. J., Appleton, G., Axton, M., Baak, A., Blomberg, N., Boiten, J.-W., da Silva Santos, L. B., and Bourne, P. E.: The FAIR Guiding Principles for scientific data management and stewardship, Scientific data, 3, 1-9, 2016.

555 Willemsen, P., Horstman, E., Borsje, B., Friess, D., and Dohmen-Janssen, C.: Decreased resilience of mangroves stressed by human interference, 2015.

Winterwerp, J. C., Albers, T., Anthony, E. J., Friess, D. A., Mancheño, A. G., Moseley, K., Muhari, A., Naipal, S., Noordermeer, J., and Oost, A.: Managing erosion of mangrove-mud coasts with permeable dams-lessons learned, Ecological Engineering, 158, 106078, 2020.

560 Zhang, K., Liu, H., Li, Y., Xu, H., Shen, J., Rhome, J., and Smith III, T. J.: The role of mangroves in attenuating storm surges, Estuarine, Coastal and Shelf Science, 102, 11-23, 2012. 


\section{Figures \& Tables}
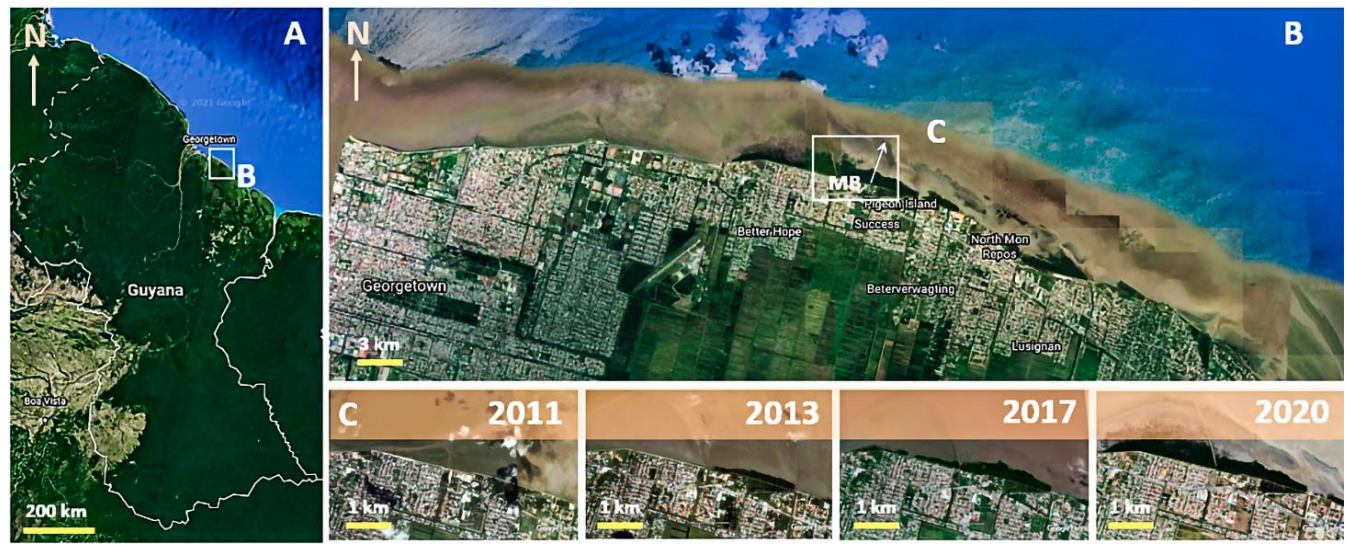

Figure 1: ( A \& B ) Satellite imagery of the data collection site along the Chateau Margot coastline located on the north eastern coastline of Guyana, with the location of the transect used for the measurements, (MB). (C) A timeline for the development of the mangrove fringe between 2011 - 2020. Here the mangrove area is shown in 2011, prior to the restoration works and in 2020. Over the last 10 years, the fringe has developed a width ranging from $120 \mathrm{~m}$ to $400 \mathrm{~m}$.

Table 1 Historical Wave Data (between the years 1969 - 1971 ) presented at locations along the coastal area of Guyana (NEDECO 1972, Van Duivendijk, et al., 1982).

\begin{tabular}{c|c|c|c|c|c|c}
\multirow{2}{*}{ Data Location } & $\begin{array}{c}\text { Distance } \\
\text { from coast } \\
(\mathbf{k m})\end{array}$ & \multirow{2}{*}{$\begin{array}{c}\text { Depth } \\
(\mathbf{m})\end{array}$} & \multicolumn{2}{|c|}{$\begin{array}{c}\text { Significant Wave } \\
\text { Height }(\mathbf{m})\end{array}$} & \multicolumn{2}{|c}{ Period (sec.) } \\
\cline { 4 - 7 } & & Average & Maximum & Average & Maximum \\
\hline $\begin{array}{c}\text { Offshore (ERA5 } \\
\text { hindcast) }\end{array}$ & 50 & $25-45$ & 1.3 & 4.0 & 6 & 13 \\
\hline $\begin{array}{c}\text { Demerara Beacon } \\
\text { (NOAA \& AWAC) }\end{array}$ & 19 & 6.5 & 0.5 & 1.3 & 8 & 12 \\
\hline Chateau Margot $(\boldsymbol{P T})$ & 1.6 & 3 & 0.4 & 0.8 & 4 & 5
\end{tabular}




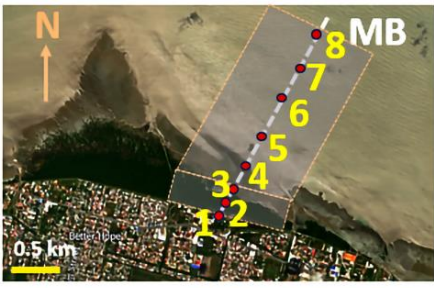

Bed Evolution from 1970 - 2020

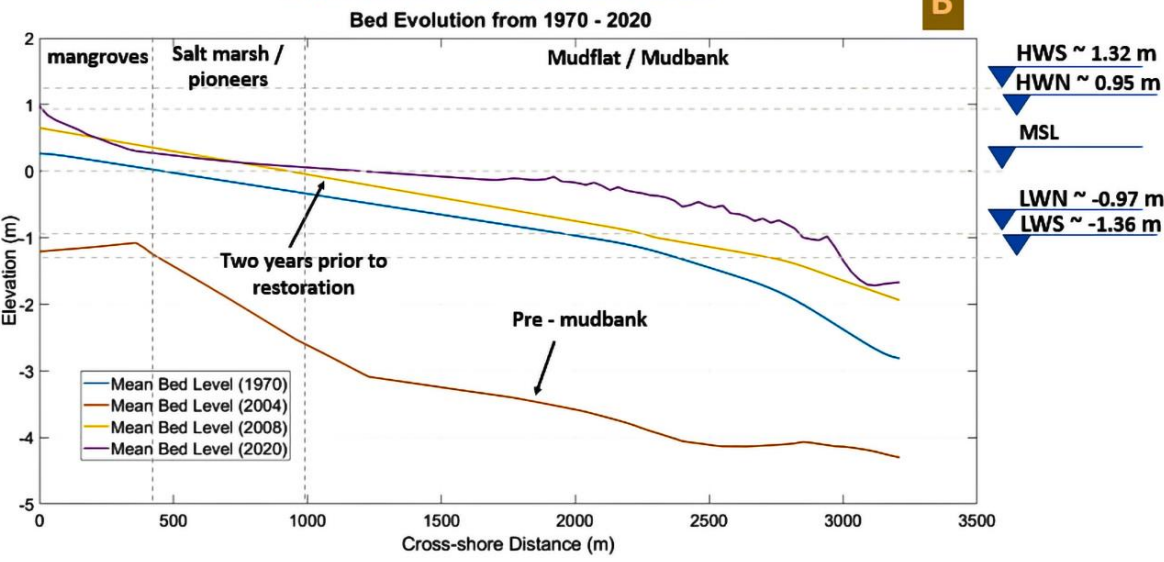

Figure 2: Overview of the alignment and bathymetric development of the transect from 1970 - 2020. (A) The north eastern alignment of the transect, MB with the instrument locations shown at the red dots. (B) The evolution of the bed level spanning the mudbank cycle: pre- mudbank presence, with the mudbank, pre- restoration and almost 10 years post restoration. Characteristic tidal water levels are indicated at the right axis $(\mathrm{HWS}=$ high water spring $\mathrm{HWN}=$ high water neap; LWN = low water neap; LWS = low water spring).

Table 2: Criteria considered for the establishment of field stations and the description of all station points outlined in Figure 2 A.

\begin{tabular}{|c|c|}
\hline $\begin{array}{l}\text { Description of Measurement Stations } \\
\text { along Transect MB }\end{array}$ & Criteria for the Selection Process \\
\hline $\begin{array}{l}\text { MB 1: relative dense forest in the back of } \\
\text { the mangrove } 23 \mathrm{~m} \text { away from the edge of } \\
\text { the toe of the concrete dyke (sea wall). }\end{array}$ & $\begin{array}{l}\text { - Mangrove fringe should be homogeneous around the } \\
\text { measurement locations, i.e. there should not be any rivers, } \\
\text { tidal creeks, sudden elevation changes or other disturbances. }\end{array}$ \\
\hline $\begin{array}{l}\text { MB 2: approximately } 100 \mathrm{~m} \text { from the toe } \\
\text { of the seawall within the mangrove. }\end{array}$ & $\begin{array}{l}\text { - The transect should consist a mudflat in front of the forest, a } \\
\text { forest fringe and an inner mangrove part (Horstman, et al., }\end{array}$ \\
\hline $\begin{array}{l}\text { MB 3: approximately } 200 \mathrm{~m} \text { from the toe } \\
\text { of the seawall within the mangrove fringe. }\end{array}$ & $\begin{array}{l}\text { 2014), which should all be convincingly flooded (more than } \\
0.20 \mathrm{~m} \text {, because of the equipment) during spring tide. }\end{array}$ \\
\hline $\begin{array}{l}\text { MB 4: the seaward edge of the mangrove } \\
\text { fringe. }\end{array}$ & $\begin{array}{l}\text { - The vegetation density should increase from the mudflat (front } \\
\text { of the mangrove forest) to the inner part of the mangrove } \\
\text { forest. At the measurement locations, the density should not be }\end{array}$ \\
\hline $\begin{array}{l}\text { MB 5, 6, 7, 8: the mudflat in front of the } \\
\text { mangrove, with MB } 8 \text { at } 1620 \mathrm{~m} \text { seaward. }\end{array}$ & $\begin{array}{l}\text { too dense, i.e. the additional flow and eddies created by the } \\
\text { vegetation should not disturb the measurements. }\end{array}$ \\
\hline
\end{tabular}



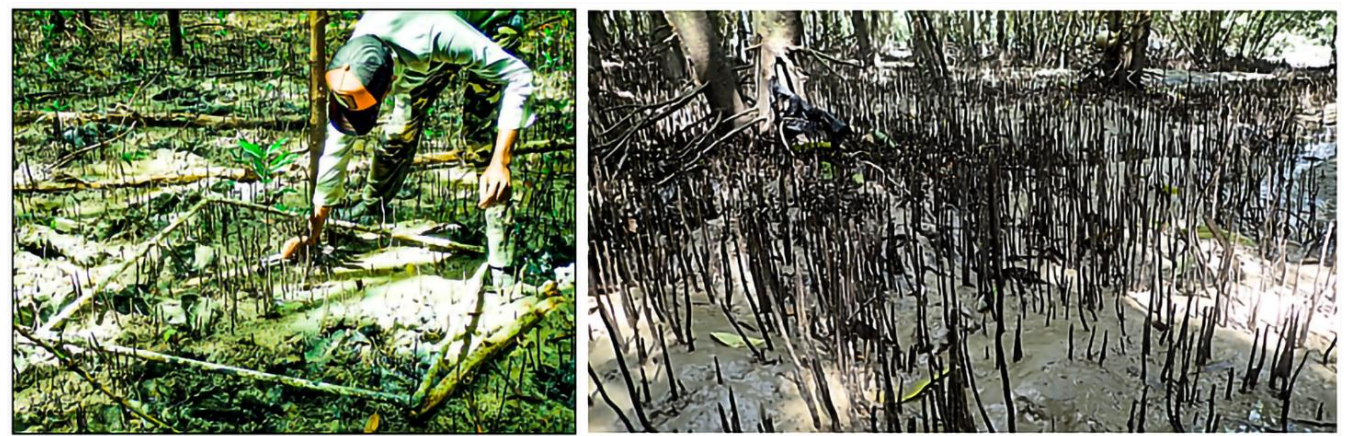

Figure 3: The setup of the vegetation quadrants and survey methodology for the vegetation data collection
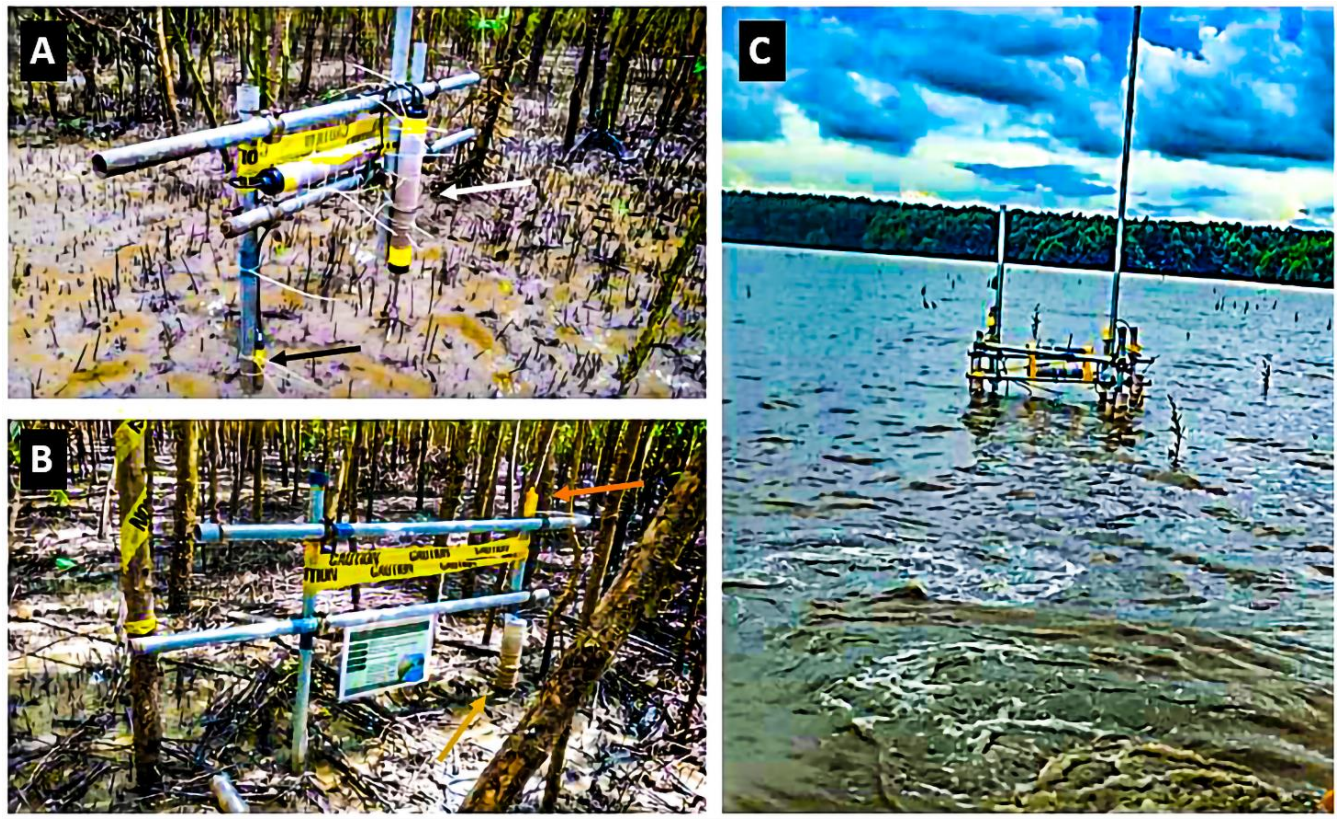

595 Figure 4: Simultaneous deployment of pressure transducers (gold arrows), acoustic doppler velocimeters (white arrow), Conductivity, Temperature \& Depth loggers (orange arrow) and the optical backscatter sensors (black arrows) at the Chateau Margot transect (MB). (A) A view of station MB 3 in the sparser Avicennia dominated forest approximately $110 \mathrm{~m}$ away from the concrete dyke. (B) A view of station MB 1 in the denser part of the Avicennia dominated forest approximately $30 \mathrm{~m}$ from the concrete dyke. (C) A view of station MB 5 (located on the mudflat) used in the test deployment and field

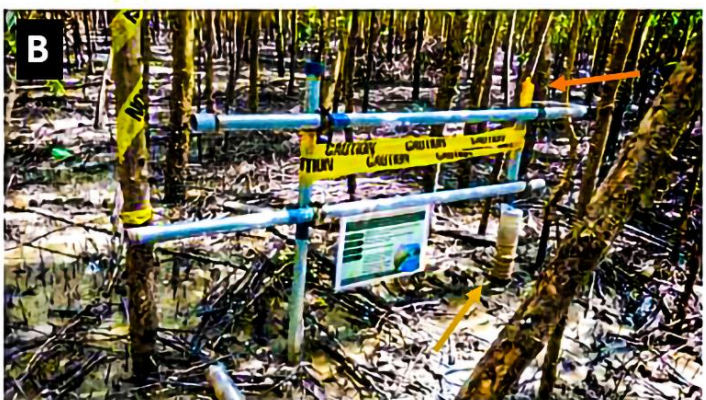
calibration of all of the instruments. 


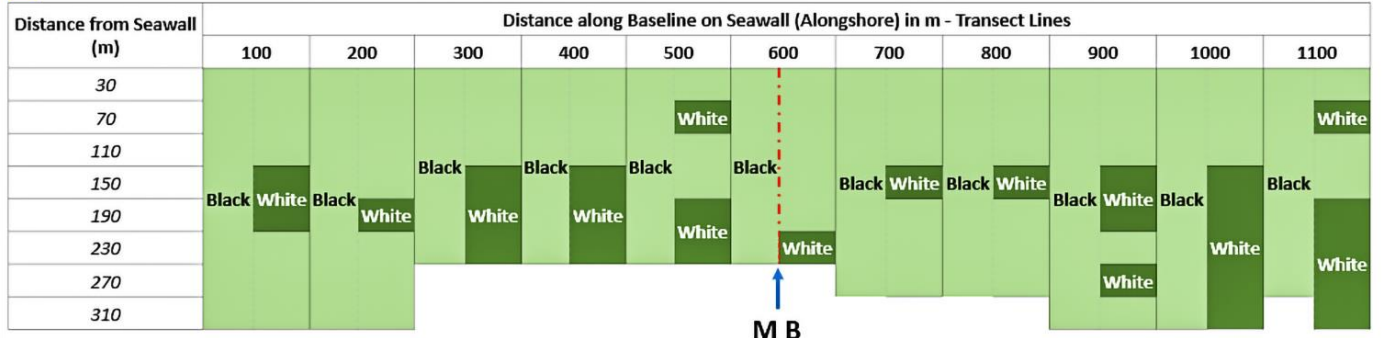

B

$$
\begin{aligned}
& \text { Density Variation across Transects for the Black and }
\end{aligned}
$$

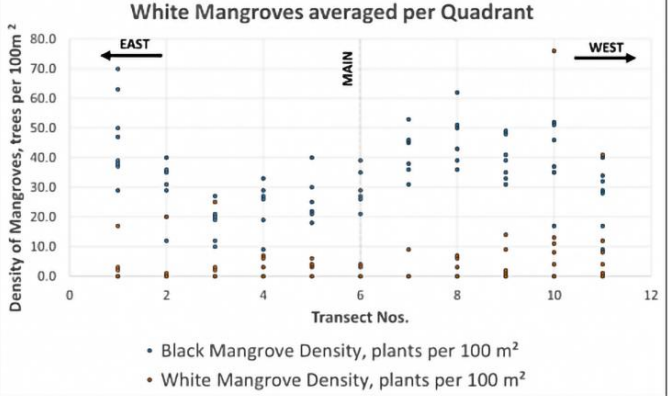

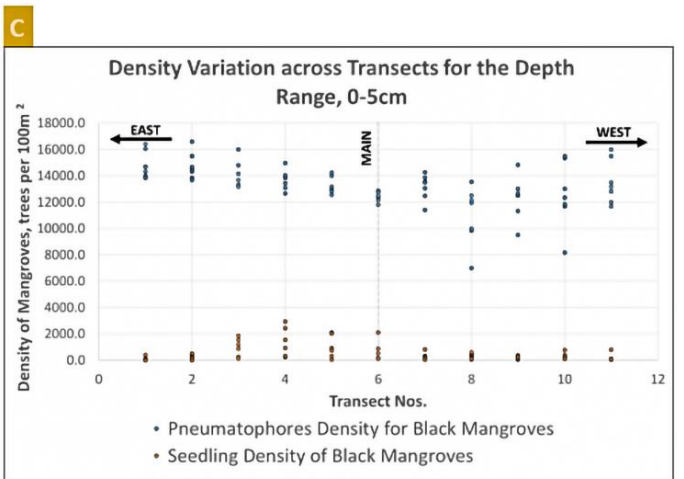

Figure 5 :Summary of the spatial variation in the mangrove species and density along the eleven transects at the Chateau Margot mangrove fringe. (A) The demarcation of zones for the two dominant mangrove species, Avicennia germinans (Black mangrove) and the Languncularia racemosa (White mangrove). (B) Variation in mangrove density (number pf plants per $100 \mathrm{~m}^{2}$ ) for the black and white mangroves. (C) Density variation along depths $0-5 \mathrm{~cm}$ for the mangrove roots (pneumatophores) and the seedlings for the Black mangroves (dominant species). Across the transects there were four (4) red seedlings. 

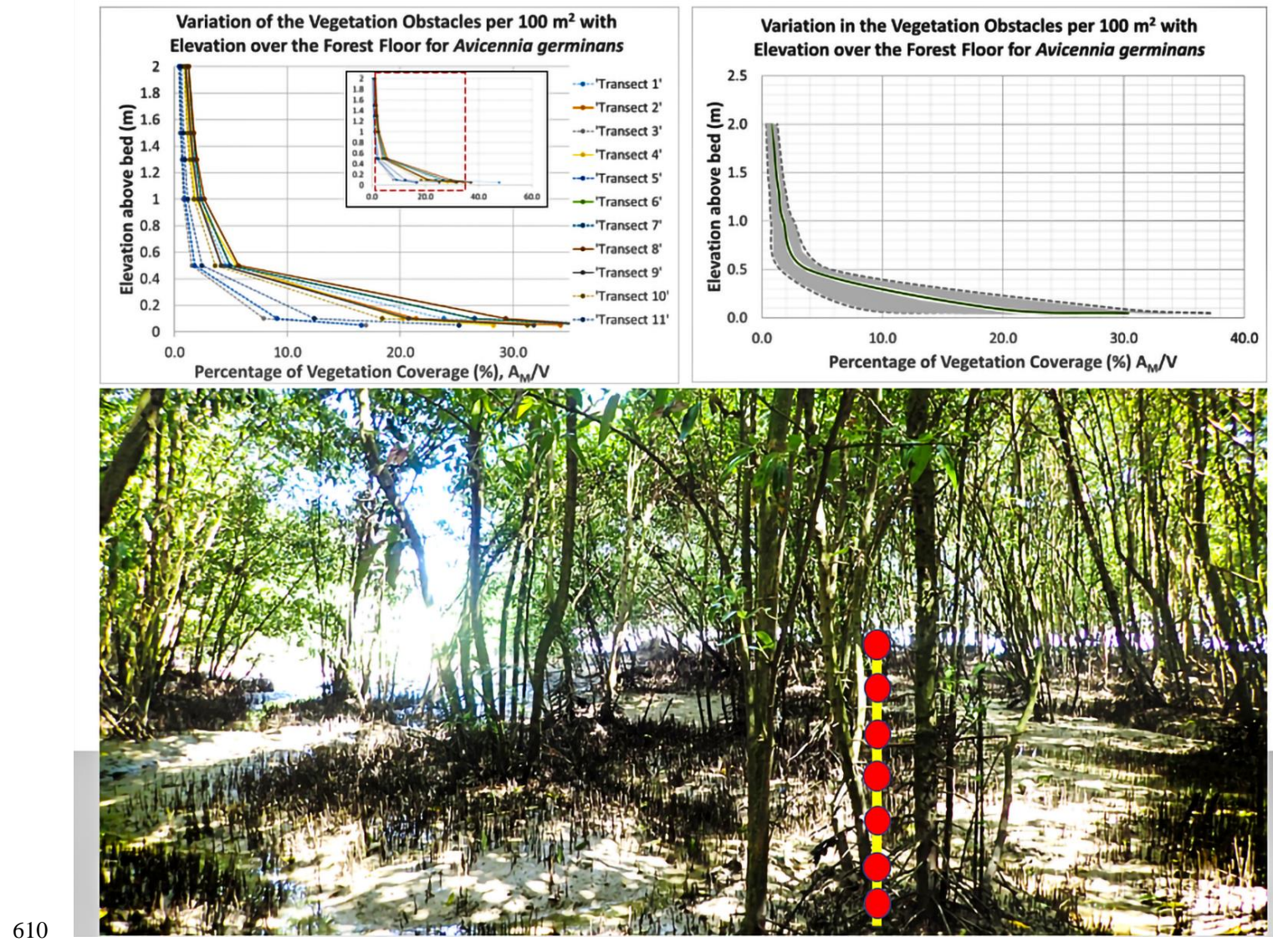

Figure 6: Variation in the vegetation density, $A_{M} / \mathrm{V}$ with elevation above the forest floor expressed as a percentage. (A) Horizontal vegetation density reduces with increasing elevation above the forest floor. (B) Vegetation characteristics for the Avicennia germinans with the measurement indicators starting from $0.05 \mathrm{~m}$ and culminating at $2 \mathrm{~m}$. 

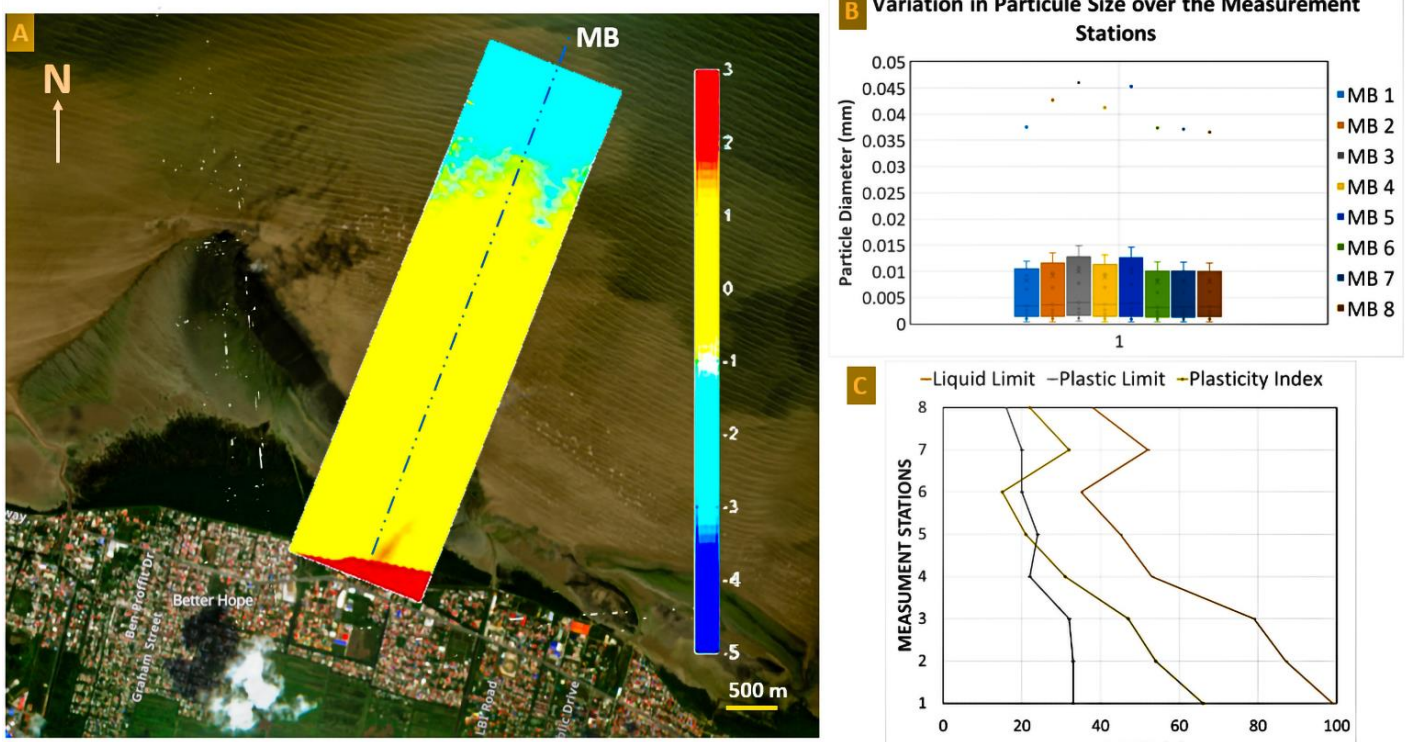

C -Liquid Limit -Plastic Limit -Plasticity Index

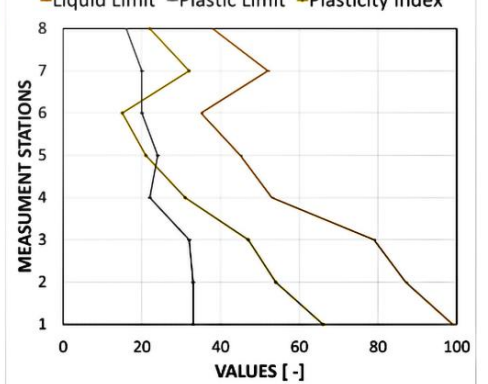

Figure 7 (A) Topographic survey of the data collection site $(1000 \mathrm{~m} \times 3500 \mathrm{~m})$, (B) Variation in the sediment particle diameters at each station point attained from the hydrometer tests, $(\mathrm{C})$ comparison of the Atterberg limits across transect, $\mathrm{MB}$.

\section{$\square 20 \mathrm{~cm}$ Depth $\square 50 \mathrm{~cm}$ Depth $\square 100 \mathrm{~cm}$ Depth}

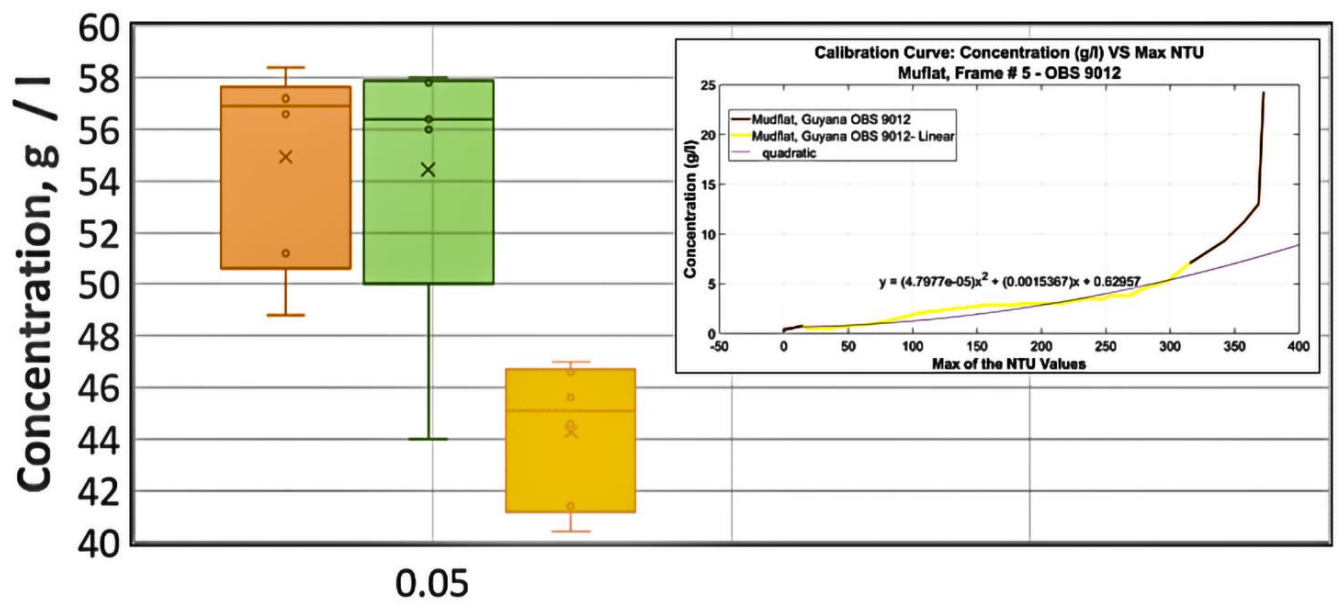

\section{Volume of Filtered Sample, [ I ]}

620 Figure 8 Variation in the suspended sediment concentration across the water depth at $20 \mathrm{~cm}, 50 \mathrm{~cm}$ and $100 \mathrm{~cm}$ above the bed level with comparison to calibration concentrations observed in the laboratory 
Table 3 Summary of the Soil Characteristics Measured at every data collection frame along the main transect

\begin{tabular}{|c|c|c|c|c|c|c|c|c|c|c|c|}
\hline Stations & $\begin{array}{c}\text { Moisture } \\
(\%)\end{array}$ & $\begin{array}{c}\text { Specific } \\
\text { Gravity } \\
(-)\end{array}$ & $\begin{array}{c}\text { Organic } \\
\text { content } \\
(\%)\end{array}$ & $\begin{array}{c}\text { Bulk } \\
\text { Density } \\
\left(\mathbf{k g} / \mathbf{m}^{3}\right)\end{array}$ & $\begin{array}{c}\text { Dry } \\
\text { Density } \\
\left(\mathbf{k g} / \mathbf{m}^{\mathbf{3}}\right)\end{array}$ & $\begin{array}{c}\text { Liquid } \\
\text { Limit }\end{array}$ & $\begin{array}{l}\text { Plastic } \\
\text { Limit }\end{array}$ & $\begin{array}{l}\text { Plasticity } \\
\text { Index }\end{array}$ & $\begin{array}{c}\text { Slump } \\
\text { (cm) }\end{array}$ & $\begin{array}{c}\text { Percent } \\
\text { passing } \\
\text { No. } 200 \\
\text { sieve }(\%)\end{array}$ & $\begin{array}{c}\text { Clay } \\
\text { Content } \\
(\%)\end{array}$ \\
\hline MB 1 & 116.98 & 2.67 & 9.09 & 1388 & 571.32 & 33.00 & 66.00 & 2.60 & 33.00 & 99.41 & 46.10 \\
\hline MB 2 & 116.71 & 2.65 & 18.10 & 1656 & 1080.00 & 33.00 & 54.00 & 5.70 & 33.00 & 98.92 & 46.17 \\
\hline MB 3 & 95.34 & 2.65 & 6.47 & 1460 & 596.89 & 32.00 & 47.00 & 4.20 & 32.00 & 99.31 & 51.29 \\
\hline MB 4 & 103.50 & 2.65 & 6.28 & 1612 & 826.43 & 22.00 & 31.00 & 8.00 & 22.00 & 98.90 & 49.16 \\
\hline MB 5 & 79.01 & 2.66 & 3.88 & 1662 & 839.95 & 24.00 & 21.00 & 8.70 & 24.00 & 99.70 & 55.86 \\
\hline MB 6 & 47.22 & 2.66 & 1.51 & 1852 & 1204.74 & 20.00 & 15.00 & 3.70 & 20.00 & 99.07 & 67.93 \\
\hline MB 7 & 87.81 & 2.64 & 3.48 & 1532 & 755.29 & 20.00 & 32.00 & 7.50 & 20.00 & 98.87 & 53.24 \\
\hline MB 8 & 60.54 & 2.68 & 2.95 & 1792 & 1260.64 & 16.00 & 22.00 & 8.90 & 16.00 & 99.60 & 62.29 \\
\hline AVG. & 88.39 & 2.66 & 6.47 & 1619.25 & 891.91 & 61.00 & 25.00 & 36.00 & 6.16 & 99.22 & 54.01 \\
\hline
\end{tabular}

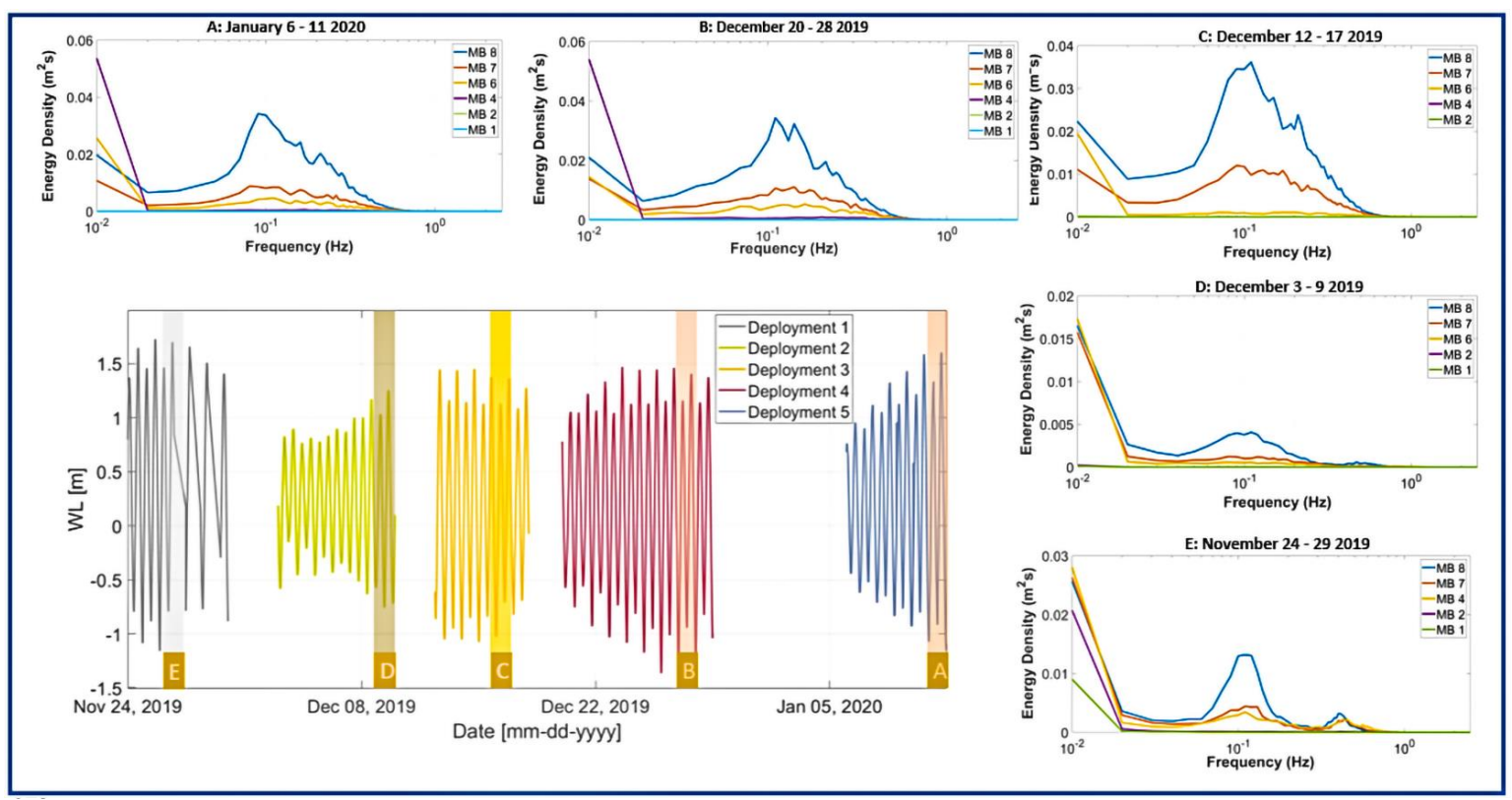

Figure 9 Averaged wave energy density spectra of simultaneously obtained wave data during full inundation of the crossshore transect, MB at Chateau Margot each for five different periods (A - E). (Lower left) Tidal conditions during the field campaign. The shaded areas in the panel represent the data collection periods of the spectra. Sensor positions (MB 1-8)refer to the positions indicated in Fig. 2. 


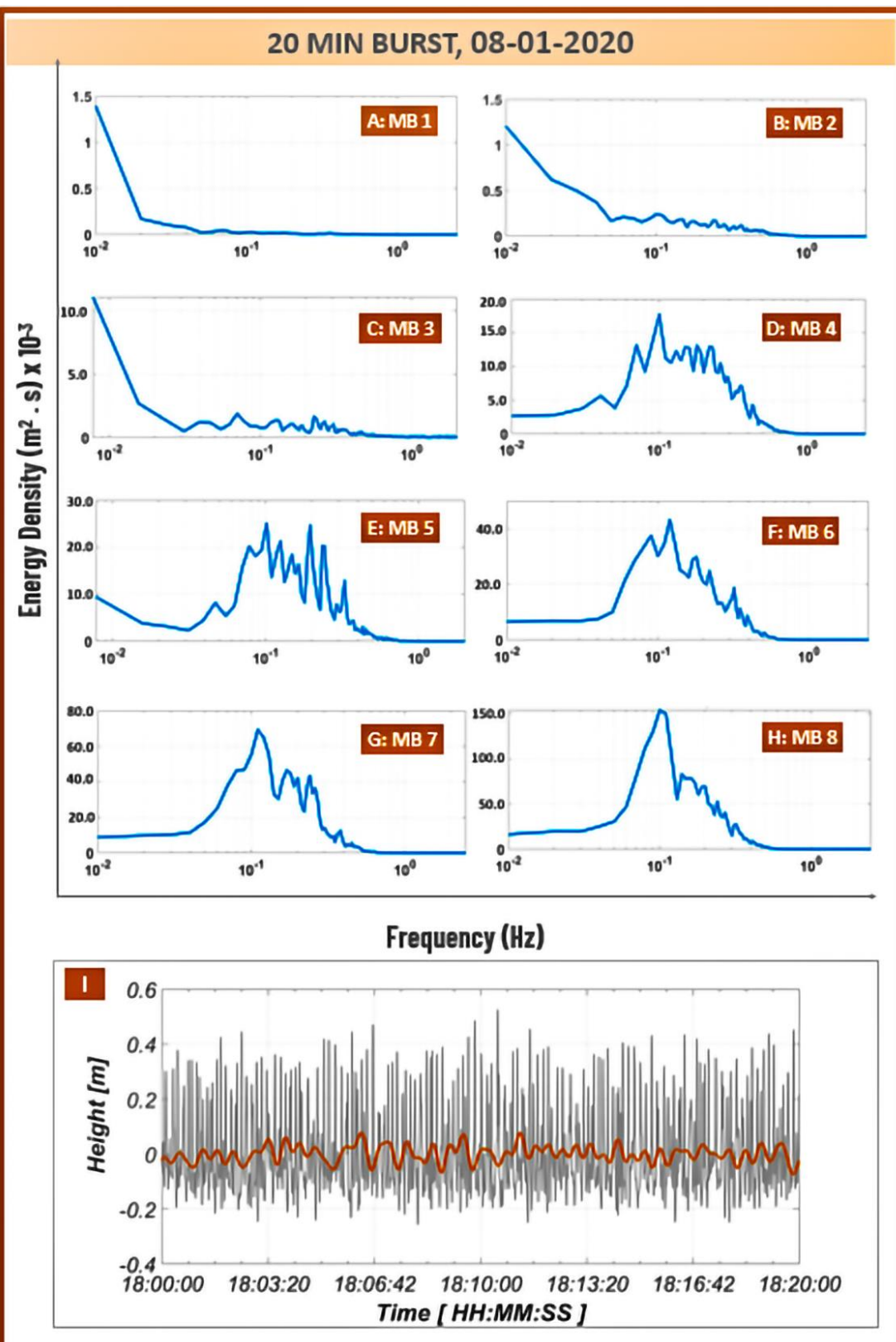

Figure 10 Averaged wave energy density spectra of simultaneously obtained wave data during full inundation of the crossshore transect (MB) at Chateau Margot, each for the period of January 6 - 11, 2020. Sensor positions, MB1 - MB8 (A -H), refer to the positions indicated in Fig. 2. The sensors located on the mudflat are MB4, MB5, MB6, MB\& and MB8 and extend from the mangrove edge to $1620 \mathrm{~m}$ offshore. In the mangrove, sensors MB1, MB2 and MB3 are placed at points $1 / 4,1 / 2$ and $3 / 4$ of the forest width. (I) Swell \& Infragravity wave bands along the coastline at position MB 8. 

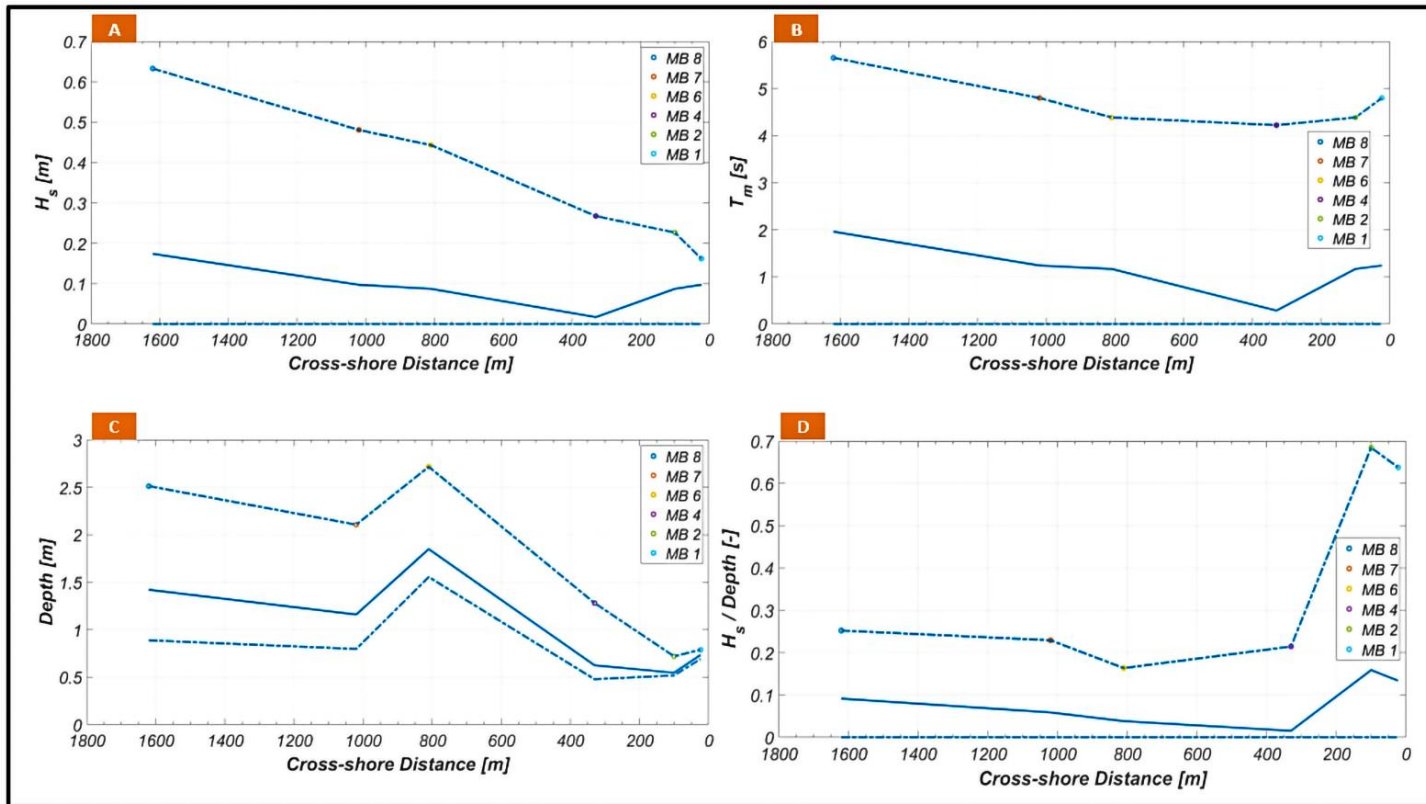

Figure 11 Spectral conditions along the transects: (A) significant wave heights $H_{s}[\mathrm{~m}]$; (B) mean wave periods $T_{\mathrm{m}}$ [s]; (C) Depth [m]; (D) wave heights divided by water depths $\mathrm{H}_{\mathrm{s}} / \mathrm{d}$ [-]; Plots of the wave characteristics present mean observed values, with bands representing the maximum and minimum values. Data comprise five days of observations spanning deployment 5.
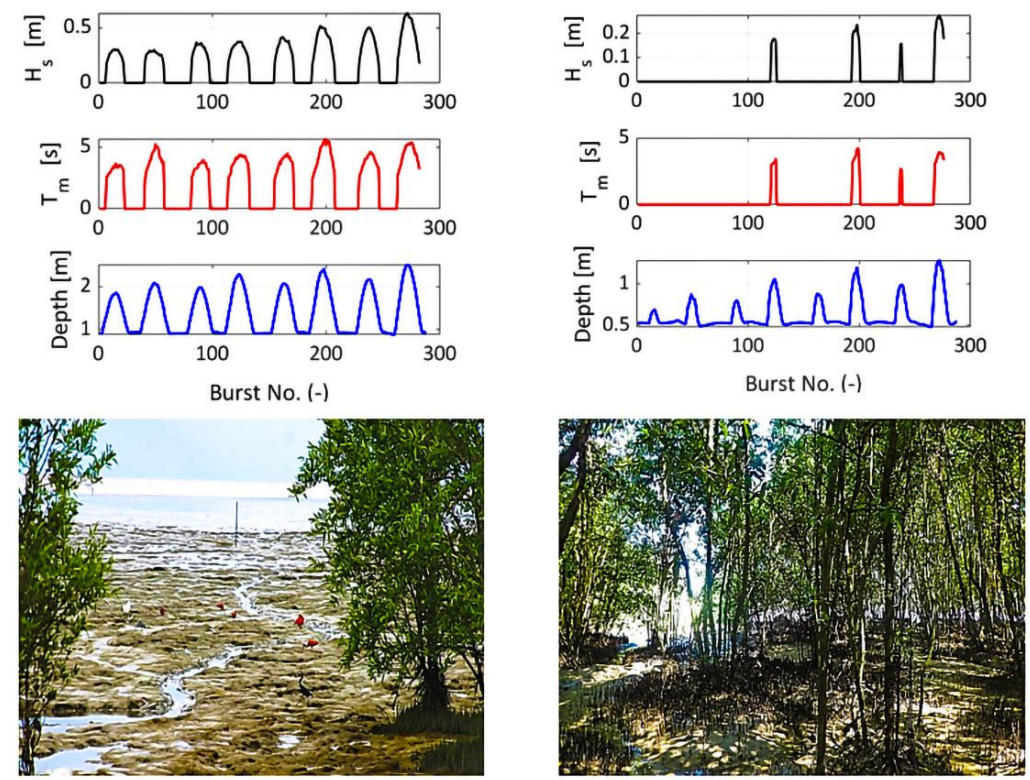

Figure 12 Wave Heights, Wave Periods and water depths (left) at location at approximately $40 \%$ of the fringe width and at (right) $1.6 \mathrm{~km}$ offshore and along the Chateau Margot coast, Guyana. 